10. Millions of Instagram influencers had their contact data scraped and exposed - Retrieved from https://techcrunch.com/2019/05/20/instagram-influencer-celebrity-accounts-

scraped/?guccounter=1\&guce_referrer_us=aHR0cHM6Ly93d3cuYmJjLmNvLnVrL25ld3Mvd29ybGQtYXNpYS1pbm RpYS00ODM0NzU5Mg\&guce_referrer_cs=25bHLb1hTJkNKXwlKGYafQ[in English].

11. Skandal u ZSU: systema upravlinnia viiskamy vyiavylasia «zakhyshchena» prymityvnymy paroliamy typu «Admin» i «123456» [Armed Forces Scandal: Troops Management System Has Been Protected by Admin and 123456 Primitive Passwords] - Retrieved from https://www.unian.ua/politics/10274616-skandal-u-zsu-sistema-upravlinnyaviyskami-viyavilasya-zahishchena-primitivnimi-parolyami-tipu-admin-i-123456.html[in Ukrainian].

12. General Data Protection Regulation (GDPR) - Retrieved from https://gdpr-info.eu/[in English].

13. Stallman R. Keep control of your computing, so it doesn't control you! - Retrieved from https://web.archive.org/web/20111226225337/https://www.gnu.org/philosophy/keep-control-of-yourcomputing.en.html[in English].

14. Google otkrыl systemu dlia analyza naborov dannыkh bez narushenyia konfydentsyalnosty [Google has opened a system for analyzing datasets without compromising privacy] - Retrieved from https://www.opennet.ru/opennews/art.shtml?num=50915[in Russian].

15. Google Analytics. Podrobnoe praktycheskoe rukovodstvo Подробное практическое руководство (2016). [Detailed practical guide] - Retrieved from https://ktonanovenkogo.ru/vokrug-da-okolo/schetchiki/hovaya-knigagoogle-analytics-podrobnoe-prakticheskoe-rukovodstvo.html [in Russian].

16. Hunt Ch., Zartaryan V. Razvedka na sluzhbe vasheho predpryiatyia [Intelligence at the service of your business].(1992). Ukrzakordonvyzaservys Kyiv, Ukraine.

Стаття надійшла до редакції 20.11.2019 р.

УДК: 338.432 .5

Філюк Дмитро, аспірант,

Східносвропейський національний університет імені Лесі Українки, кафедра обліку та аудиту,

м. Луцьк ORCID ID 0000-0002-2678-3424 e-mail:0666763009@ukr.net

\author{
https://doi.org/10.29038/2411-4014-2019-04-124-132
}

\title{
СЕЛЕКЦІЯ - ВАЖЛИВА СКЛАДОВА ЗРОСТАННЯ ЕКОНОМІЧНОГО ПОТЕНЦІАЛУ БДЖІЛЬНИЦТВА
}

У статті проаналізовано ситуацію у сфері селекційної діяльності в Україні та розглянута роль селекції в збільшенні виробничої продуктивності бджологосподарств. Розкриті досягнення, проблеми і завдання селекції на сучасному рівні розвитку сільськогосподарського виробництва. Доведено, що селекція найдешевший, найрезультативніший та екологічно чистий чинник зростання виробництва продукції тваринництва. Визначено пріоритети стратегій і планів дій щодо генетичних ресурсів для виробництва продовольства і ведення сільського господарства. Відмічено, що реальні можливості сільського господарства України, зокрема бджільництва, задля зростання економічної ефективності та конкурентоспроможності галузі повинні складатися із найважливіших чинників які необхідно реалізовувати за допомогою розроблення загальнодержавної стратегії ефективних програм селекції. Запропоновано напрями i заходи щодо стимулювання розвитку селекції в контексті підвищення економічної ефективності бджільництва.

Ключові слова: порода, генетичні ресурси, селекція, селекційна діяльність, племінна робота, ефективність, продуктивність, оцінка продуктивності. 


\section{СЕЛЕКЦИЯ - ВАЖНАЯ СОСТАВЛЯЮЩАЯ РОСТА ЭКОНОМИЧЕСКОГО ПОТЕНЦИАЛА ПЧЕЛОВОДСТВА}

В статье проанализирована ситуация в сфере селекционной деятельности в Украине и рассмотрена роль селекции в увеличении производственной производительности пчелохозяйство. Раскрыты достижения, проблемы и задачи селекции на современном уровне развития сельскохозяйственного производства. Доказано, что селекция дешевый, самый и экологически чистый фактор роста производства продукции растениеводства и животноводства. Определены приоритеты стратегий и планов действий по генетическим ресурсам для производства продовольствия и ведения сельского хозяйства. Отмечено, что реальные возможности сельского хозяйства Украины, в частности пчеловодства, для указанного повышения экономической эффективности и конкурентоспособности отрасли должны состоять из важнейших факторов, которые необходимо реализовывать с помощью разработки общегосударственной стратегии эффективных программ селекции. Предложены направления и мероприятия по стимулированию развития селекционной деятельности в контексте экономической эффективности пчеловодства.

Ключевые слова: порода, генетические ресурсы, селекция, селекционная деятельность, племенная работа, эффективность, производительность, оценка производительности.

Filiuk Dmytro, graduate student,

Lesya Ukrainka Eastern European National University, department of accounting and auditing,

Lutsk

\section{SELECTION - AN IMPORTANT COMPONENT OF INCREASING THE ECONOMIC POTENTIAL OF BEEKEEPING}

The revival of beekeeping should be aimed at fully meeting the needs of the market with competitive products of the industry. It has to be done based on expanded reproduction of the number of bee families, increasing their genetic potential. Also, must be an improvement of the existing and creation of new breeds of bee, which are well-adapted to natural conditions, the introduction of the intensive technologies of retention, improvement of partnerships between the farms-producers with raw materials and processing enterprises.

The purpose of this article is to analyze and summarize the prospects of breeding work aimed at increasing the economic potential of beekeeping in the context of the economic efficiency of beekeeping. This article also defines the economic principles used to ensure the efficiency of pedigree selection as one of the main directions for improving the productivity of bee families.

The article analyzes the situation in the field of breeding activities in Ukraine and considers the role of breeding in increasing the productivity of beekeeping farms. It also reveals the achievements, problems, and tasks of breeding at the current level of agricultural production development. It is proved that breeding is the cheapest, the most effective and environmentally-friendly factor in the growth of livestock production. This article identifies priorities of the strategies and action plans for genetic resources for food production and agriculture.

The strategic direction of the development of breeding work in beekeeping is to increase the productivity of bee families and resistance to pests. Achieving beekeeping efficiency, which is expressed in the ratio of useful results of its operation to the resources spent, it is possible to implement methods and techniques based on the scientific organization of labor, the progressive experience of developed countries, and the achievements of agrarian and economic sciences in this field.

Beekeeping must be developed on an industrial basis. The above factors affect the productivity of the economy and the reduction of costs of material and labor resources. The implementation of directions and measures to stimulate the development of breeding activities in the context of the economic efficiency of beekeeping will help to increase the productivity of bee families, reduce material and monetary costs per one bee family.

Keywords: breed, genetic resources, breeding, breeding activity, breeding work, economic efficiency, performance evaluation. 
Постановка проблеми та їі значення. Бджільництво - особлива і надзвичайно цінна галузь сільського господарства України, розвиток якої значною мірою визначає продовольчу безпеку держави та якість харчування населення [1]. Відродження бджільництва має бути спрямоване на повне забезпечення потреб ринку конкурентоспроможними продуктами галузі на основі розширеного відтворення чисельності бджолиних родин та підвищення їх генетичного потенціалу, реструктуризації кормової бази, поліпшення утримання, удосконалення існуючих і створення нових порід бджіл, що добре пристосовані до природнокліматичних та господарсько-економічних умов, впровадження інтенсивних технологій утримання, вдосконалення партнерських взаємовідносин між господарствами-виробниками сировини та підприємствами з ії переробки.

Аналіз останніх досліджень і публікацій. Дослідженням процесів розвитку та функціонування галузі бджільництва приділено увагу таких вчених як В.Алпатов, А. Бойко, А. Бутлеров, Г.Кожевников, Н. Кулагін, В.Поліщук, П.Прокопович, В. Малков, А. Кетле, Ф. Руттнер, Л. Армбрустер та інші. Вони в тій чи іншій мірі розкривають методичні та практичні аспекти розвитку та функціонування галузі бджільництва. Віддаючи належне наявним здобуткам науковців, зазначимо, що за сучасних умов розвитку сільськогосподарського виробництва, з утвердженням різних організаційних форм господарювання роль бджільництва зростає. Бджільництво має розвиватися на промисловій основі та лише об'єднуючи всі фактори які мають дійсний вплив на продуктивність бджолиної родини в збалансованому вигляді, можна досягти зменшення затрат матеріальних та трудових ресурсів.

Мета і завдання статті - проаналізувати й узагальнити перспективи селекційної роботи, спрямованої на зростання економічного потенціалу бджільництва, в контексті економічної ефективності бджільництва. Визначення економічних засад забезпечення ефективності селекційноплемінної роботи як одного з головних напрямів підвищення продуктивності бджолиних сімей.

Викладення основного матеріалу та обгрунтування отриманих результатів:

Стратегічним напрямом розвитку сільського господарства $\epsilon$ досягнення сталого та високоефективного виробництва продукції, що $\epsilon$ важливою складовою збалансованого функціонування економічної, соціальної та екологічної складових національної економіки, спрямованих на забезпечення раціонального використання всіх видів ресурсів. При цьому, особливої уваги набувають проблеми забезпечення населення країни якісними та екологічно безпечними продуктами харчування, підвищення рівня продовольчої безпеки, збереження біорізноманіття та відтворення природної флори і фауни держави [2].

Україна позиціонує себе в міжнародному співтоваристві як потужний агровиробник і експортер, при цьому одним з експортоорієнтованих напрямків, здатних забезпечити світове лідерство України, $\epsilon$ бджільництво, а ринок меду - один з небагатьох, на яких Україна є лідером, забезпечуючи до 5\% світового виробництва меду (приблизно 1,5 млн т на рік). У 2018 році Україна лідирувала в Свропі та займала 3-тє місце в світі за обсягами виробництва після Китаю, Туреччини та Аргентини. [3], [4].

Зміни які відбуваються в сільському господарстві потребують забезпечення переходу на промислову та інноваційну основи, що супроводжується впровадженням методів і прийомів, які грунтуються на науковій організації праці, прогресивному досвіді розвинених країн і досягненнях аграрної та економічної наук у даній сфері. Проте застосування нових прогресивних технологій ведення бджільництва та виробництва меду значно підвищує його собівартість. Отже, українське бджільництво потребує забезпечення підвищення продуктивності іншими способами.

За сучасних умов розвитку сільськогосподарського виробництва, 3 утвердженням різних організаційних форм господарювання роль бджільництва зростає. Бджільництво має розвиватися на промисловій основі та лише об'єднуючи всі фактори котрі мають дійсний вплив на продуктивність бджолиної родини в збалансованому вигляді, можна досягти зменшення затрат матеріальних та трудових ресурсів.

Оскільки селекція - найдешевший, найрезультативніший та екологічно чистий чинник зростання виробництва продукції рослинництва та тваринництва. За сучасних тенденцій підвищення вартості енергозатрат на одиницю виробленої продукції і за наявності проблем, що виникли внаслідок загрозливого забруднення навколишнього природного середовища, селекції відводиться особливо важлива економічна i суспільна роль. Впливаючи безпосередньо на підвищення продуктивності сільського господарства, селекція перетворюється на засіб виробництва. У цілому 
людство має у своєму розпорядженні величезні резерви для збільшення харчових ресурсів, особливо сільськогосподарської продукції [5].

Оскільки Україна володіє значними цінними генетичними ресурсами трьох аборигенних порід бджіл, а саме: карпатська, поліська, українська степова, які з давніх часів населяють територію нашої держави та виникли тут у процесі еволюції. Генетичні ресурси бджіл українських порід національне багатство держави Україна, оскільки дані породи становлять значний інтерес для бджолярів, вчених-селекціонерів, так як володіють цінними господарсько-корисними характеристиками притаманними тільки їм та потребують збереження, вдосконалення i раціонального використання.

При цьому племінна робота в бджільництві передбачає комплекс зоотехнічних, селекційних та організаційно - господарських заходів, спрямованих на поліпшення племінних і продуктивних якостей бджіл та збереження генофонду існуючих і зникаючих порід. Селекція, як невід'ємна складова цього процесу, пов'язана з відбором якісних бджолосімей за їх продуктивністю і іншими корисними властивостями, які обумовлені спадково. Ефективність відбору на пасіці за біологічними ознаками бджіл у сім'ї, визначається мірою спадкового поліпшення кожного нового покоління в порівнянні з попереднім.

Перші публікації про специфіку розмноження бджіл на генетичному рівні зробив німецький професор Л. Армбрустер, опублікувавши в 1919 році книгу „Наука розведення бджіл” де було розкрито теоретичні аспекти розведення бджіл на базових принципах розмноження, що грунтуються на основі законів генетики Менделя [6].

В своій книзі „Наука розведення бджіл” Армбрустер приводить три цілі розведення бджіл : а) спортивна; б) наукова; в) економічна.

Очевидно, що на рівні економічного розвитку сільського господарства та бджільництва в цілому, головне завдання - економічна мета розведення, що базується на комерційній основі та дозволяє отримати максимальну продуктивність виробництва продукції з однієї бджолородини 3 мінімальними затратами часу та трудових ресурсів.

Важливими чинниками, що впливають на кінцеві результати селекції в бджільництві на думку В. Малкова $є$ біологічні та економічні умови ефективності здійснення селекції.

Серед біологічних умов, що сприяють селекції, можна виділити наступні: 1) швидка зміна поколінь; 2) висока плодовитість; 3) характер ознак які мають головне значення.

Серед економічних ознак можна назвати наступні: 1) низька вартість бджолиної особи; 2) значне економічне значення об'єкта селекції [7].

В 1970 році Ф. Сладен опублікував доповідь в британському Журналі Бджільництва (British Bee Journal), щодо проведеного дослідження по створенню нової комбінації від схрещення староанглійської та золотої італійської лінії бджіл, де теоретично дослідження базувались на відкриттях Менделя. Так вперше було отримано результати племінної роботи в галузі бджільництва які мали значну економічну цінність та подальший вплив на розвиток бджільництва [6].

Таблиия 1

Комбінаційна можливість порід бджіл до збільшення виробництва продукції *

\begin{tabular}{|c|c|c|c|}
\hline № & $\begin{array}{c}\text { Комбінація } \\
\text { схрещення- породи } \\
\text { бджіл }\end{array}$ & $\%$ & Примітка \\
\hline 1 & карніка х темна лісова & 31 & порівнянно до кращих відібраних ліній породи карніка \\
\hline 2 & карніка х кавказька & $50-100$ & порівнянно до відібраних ліній породи карніка \\
\hline 3 & $\begin{array}{c}\text { кавказька х темна } \\
\text { лісова }\end{array}$ & $15-45$ & $\begin{array}{c}\text { порівнянно до середньої продуктивності батьківських } \\
\text { ліній }\end{array}$ \\
\hline 4 & $\begin{array}{l}\text { кавказька х українська } \\
\text { степова }\end{array}$ & $61-65$ & порівнянно до конрольної украхнської степової \\
\hline 5 & анатолійська х бакфаст & $128-151$ & порівняно до середньопасічного медозбору \\
\hline
\end{tabular}

* Джерело: [12] 
Науковці в галузі бджільництва зазначають перспективи стратегічного планування схрещення різних географічних видів бджіл та вказують, що комбінаційна властивість у бджіл варіюється в межах певних господарсько - економічних характеристик, що дозволить отримати поєднання властивостей різних видів.

3 теоретичних позицій, щодо методів оцінки племінної цінності бджіл, які використовуються в селекційній практиці, розробив і систематизував Ф. Руттнер на початку 70 -х років XX сторіччя. Саме 3 цих позицій виникли основні якісні характеристики оцінки продуктивності, розроблені міжнародною авторитетною комісією за дорученням об'єднання Apimondia в 1972 році які були опубліковані у вигляді директиви. Приведені рекомендації даної директиви, дозволяють досягнути об'єктивності та порівняння при проведенні оцінки продуктивності і господарсько - корисних ознак бджолиної родини, за наступними характеристиками:

- медопродуктивність;

- весняний розвиток;

- активність відбудови стільників;

- строкатість розплоду;

- миролюбність;

- поведінка бджіл на стільниках під час огляду;

- стійкість до вароозу;

Підсумком проведеної роботи є оцінка продуктивності по родоводу, адже суть селекційної роботи полягає в передачі рекордної продуктивності максимально більшій кількості нащадків, при цьому не зменшивши господарсько - корисних ознак а по можливості збільшивши їх.[8]

Зокрема селекція медоносних бджіл відбувається в постійному підборі бджолиних родин носіїв високої медової продуктивності та покращення таких господарсько-корисних ознак властивих бджолам: працелюбність, помірна рійливість, миролюбний характер, активність в зборі нектару, стійкість до хвороб.

Практика країн Європи свідчить, що на основі широкого застосування селекційної роботи в сільському господарстві зокрема в бджільництві вдалося вдвічі-втричі й більше підвищити продуктивність.

Оскільки повна реалізація потенційних можливостей бджільництва значною мірою залежить від рівня здійснення селекційної роботи. Так, з метою покращення ситуації у галузі бджільництва, пропонується застосування програми селекційної роботи, що безсумнівно є одним 3 факторів, значного збільшення товарної продуктивності бджолиних родин. Господарсько - економічні переваги ще більші, за очікувані, по причині виробничих витрат, які завжди приблизно однакові, а збільшення товарної продуктивності на $25 \%$ завдяки селекції означає, що чистий прибуток після вирахування затрат підвищився на $50 \%$.

Як свідчать результати досліджень німецьких та австрійських селекціонерів по вивченні продуктивності бджолиних родин, що систематизовані в роботах проф. К. Бінефельда які відбувалися протягом 23 років на 5,7 тис. бджолородин, свідчать про повільне зростання продуктивності $(0,25$ кг/рік), що типово для результатів селекції інших тварин (наприклад, у курей 1 яйце/рік). При цьому збільшення продуктивності відбувається не по окремих бджолиних родинах, а за рахунок середньої продуктивності всієї пасіки [8].

Дослідження продуктивності бджолиних родин за 30 років здійснення селекційної роботи в Північній Німеччині, здійсненне проф. Бинфельдом та спеціалістом з племінної роботи Тизлером, дозволило встановити постійний ріст середньої продуктивності бджолиних родин. Постійний ріст продуктивності був обумовлений не тільки генетичними ознаками, а в значній мірі зміною умов медозбору та покращенням організації утримання бджіл.

Таким чином, завчасне впровадження програми селекції дозволить крім підвищення середньої продуктивності всієї пасіки досягти, за умови включення показника стійкості бджіл до хвороб та реалізації селекційно-генетичних програм, що дозволить створити лінії бджіл 3 вищим індексом племінної цінності, це сприятиме не тільки збільшенню виробництва продуктів харчування, а й поліпшенню їхньої якості. 


\section{Підвищення продуктивності бджолиних родин за період селекційної діяльності}

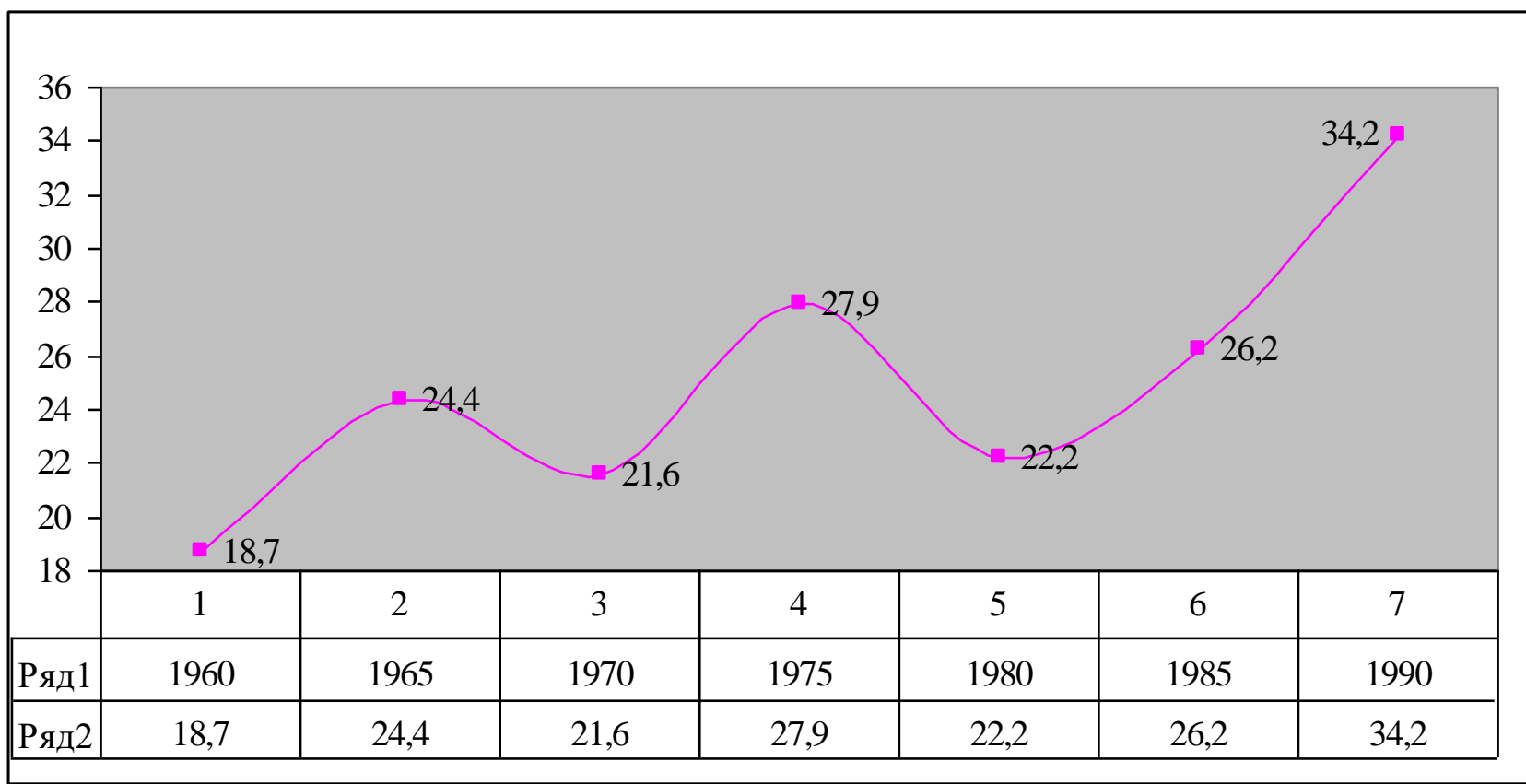

Джерело: [8]

Нині селекційні дослідження спрямовані на поглиблення знань про успадкування кількісних і якісних ознак, стійкість до стресових чинників довкілля і використання цих знань 3 метою створення вихідного матеріалу для селекції високопродуктивних ліній бджіл.

Аналіз діяльності селекційних підрозділів Національної академії аграрних наук України (НААНУ) підтверджує наявність певних досягнень у зазначеній сфері, які, однак, малою мірою позначаються на загальному незадовільному стані вітчизняної селекції та ринку селекційної продукції.[9]

У 1989 році при Інституті бджільництва ім. П.І. Прокоповича був створений відділ селекції та репродукції карпатських бджіл. Зусилля його науковців здебільшого спрямовані на пошук чистопородних карпатських бджолосімей з метою їх збереження, вдосконалення і раціонального використання [10]. За останнє десятиріччя в Інституті бджільництва імені П.I. Прокоповича відселекціоновано високопродуктивні типи карпатських бджіл: "Вучківський“, "Рахівський” та "Говерла", які затверджено Наказом Міністерства аграрної політики України та Української академії аграрних наук № 85/9 від 25 лютого 2010 року. Призначення типів: для товарних та племінних пасік. Бджолині сім'ї відповідають встановленим вимогам до екстер'єру та біологічних ознак карпатських бджіл; мають підвищену на 15-20 \% медову та воскову продуктивність, зимостійкі, миролюбиві.

Водночас у селекційній роботі в Україні основний акцент зроблено на виведенні більш продуктивних порід бджіл та практично відсутні кроки до поліпшення якісних показників та підвищення резистентності бджіл,. Так, не надається належна увага такому важливому напряму селекційної роботи, як створення або використання виведених іноземними дослідниками стійких ліній бджіл до хвороб, зокрема вароозу які відібрані за ознаками гігієнічної поведінки. Розвинені країни досить давно розпочали перехід до використання такого племінного матеріалу у промисловому бджільництві, оскільки стійкі до хвороб бджоли, на відміну від звичних мають покращенні ознаки стійкого імунітету, а отже, вимагають менше догляду. Відомо, що в Німеччині нині ведеться планомірна селекційна робота по покращенню якісних характеристик бджіл, стійких до захворювань, а в перспективі перевага надаватиметься лише бджолам стійким до захворювань.[8].

Подібна ситуація викликає значне занепокоєння спеціалістів галузі не лише внаслідок посилення імпортної залежності і реальної перспективи остаточного занепаду вітчизняної селекційної діяльності, але й через те, що, як відомо, найкращі виробничі й економічні показники 
демонструють породи, найбільшою мірою адаптовані до місцевих умов. Крім цього, враховуючи, що зарубіжні селекціонери насамперед орієнтуються на можливості власних виробників, які мають достатні фінансові ресурси для використання оптимальних технологій утримання. Чинник недостатньої фінансової забезпеченості більшості українських бджологосподарств $\epsilon$ одним із найсуттєвіших обмежень і в процесі розвитку вітчизняного бджільництва. В Україні на перше місце виходить технологічна незабезпеченість пасічної галузі, що не дозволяє утримувати бджолині родини відповідно до рекомендованих технологій. Так, повсюдні порушення умов утримання бджолиних родин призвели до ослаблення сили родин та розвитку захворювань, які потребують якнайшвидшого реагування зі сторони ветеринарної медицини. [8].

При цьому, бджолині сім’і можуть повністю проявити свої цінні господарсько - корисні властивості тільки при створенні для них сприятливих умов життєдіяльності. Одна 3 найважливіших вимог селекційно-племінної роботи з поліпшення якості бджолиних сімей є стабільне забезпечення бджіл кормами. Для цього необхідно створити їм достатню медоносну базу використовуючи об'єднані та почергові взятки 3 ентомофільних сільськогосподарських культур та дикорослих медоносів. Тільки при організації регулярної кочівлі бджіл до додаткових джерел медозбору, може повністю проявитися спадковість таких важливих ознак, як медо i воскопродуктивність та поведінкові характеристики бджолиних сімей.

Відтоді як К. Ліней присвоїв наукову назву медоносній бджолі Apis mellifera L. відбулося відкриття нових популяцій бджіл так і безцінна втрата деяких 3 них, зокрема кримської бджоли. 3 метою збереження генофонду цінних аборигенних порід бджіл - української степової, карпатської та поліської, затверджено спільний наказ міністерством Аграрної політики України та Українською академією аграрних наук України від 20 вересня 2000 року за № 184/82 який визначає план породного районування бджіл в Україні. Зокрема збереження, репродукція та поліпшення аборигенних (місцевих) бджіл в ареалах їх природного розселення здійснюються на основі принципу збереження та поліпшення цих порід, який склався в тих чи інших природно - кліматичних умовах.

Породне районування бджіл є основою раціонального розміщення і використання племінних ресурсів держави. Породне районування бджіл це науково - обгрунтований відбір для розведення i господарського використання в конкретних регіонах таких порід бджіл, біологічні особливості яких найкращим чином відповідають типовим умовам клімату і медозбору цих регіонів, дозволяють їм виробляти в цих умовах значно більше продукції в порівнянні з іншими породами на фоні достатньої зимостійкості бджіл.

3 метою розмноження кращих бджолиних родин - носіїв високої медової продуктивності наказом Міністерства аграрної політики та продовольства України від 13 квітня 2016 року N 155 затверджено „Технологічні вимоги для проведення селекційно-племінної роботи в галузі бджільництва", де при бонітуванні оцінюють породність бджолиних сімей та три основних показники - силу сім'ї, зимостійкість та медову продуктивність. Суб'єктам господарювання які займаються збереженням існуючого генофонду, поліпшенням племінних якостей бджолиних сімей відповідно до конкретних кліматичних умов та з урахуванням кормової бази відповідно до чинного законодавства може бути присвоєно статус - племінний завод, племінна пасіка, племінний бджолорозплідник.

Українська держава робить певні кроки щодо розвитку селекції бджіл. Зокрема, ця сфера регламентується Законами України "Про бджільництво" від 22.02.2000 № 1492-III, „Про племінну справу у тваринництві” від 23.12.1993 № 3773-XXI, у 2004 р. було ухвалено Закон України "Про Загальнодержавну програму селекції у тваринництві на період до 2010 року" (який регламентував організаційні, науково-методичні аспекти селекційно-племінної справи у тваринництві та пї фінансову підтримку державою), постановою Кабінету Міністрів України від 22 серпня 2011 р. N 886 затверджено «Порядок використання коштів, передбачених у державному бюджеті для виконання програми селекції у тваринництві та птахівництві в науково-дослідних господарствах», наказом міністерством Аграрної політики та продовольства України від $19.06 .2019 \quad № 234$ затверджено «Порядок присвоєння відповідного статусу суб'єктам племінної справи у тваринництві та Технологічних вимог до проведення селекційно-племінної роботи в галузі бджільництва» та спільний наказ з Українською академією аграрних наук від 12.10.2007 №735/97 «Про проведення навчання i атестації працівників, які виконують спеціальні роботи, пов'язані 3 племінними 
(генетичними) ресурсами у бджільництві». Діють також щорічні програми бюджетної підтримки селекції , реалізовувалася галузева Програма "Селекція і насінництво - 2006-2010" [10], із 1 січня 2010 р. набув чинності Закон України "Про ідентифікацію та реєстрацію тварин" [11] (яким, зокрема, передбачено оптимізувати розробку і виконання селекційних програм, підвищити достовірність інформації при сертифікації племінних (генетичних) ресурсів), розроблено проект Концепції Загальнодержавної цільової програми селекції у тваринництві [10], [11].

Розвиток селекційної діяльності має розглядатися в контексті загального процесу функціонування аграрного сектору національної економіки, основними завданнями якої $\epsilon$ забезпечення кількісного та якісного зростання інноваційних пропозицій, підвищення сприйнятливості виробників до нововведень, а також формування ефективної "провідної" мережі від науки до виробництва. Визначальна роль у досягненні цього належить державі, яка повинна не лише вибудувати основи розвитку даної системи і розробити сукупність дієвих механізмів взаємодії ії складових, але й стимулювати розвиток у відповідному напрямі вітчизняної фундаментальної науки, а також сприяти придбанню і трансферу прогресивних технологій виробництва агропродовольчої продукції, у тому числі й у межах міжнародних дослідницьких проектів. В Україні, як відзначалося, неодноразово приймалися різні документи (плани, концепції, програми тощо), метою яких було стимулювання розвитку селекції у рослинництві і тваринництві. Тому з метою нарощування конкурентоспроможності вітчизняної продукції на внутрішньому та зовнішньому ринках насамперед треба забезпечити підтримку розвитку саме напряму селекції [9].

Проте, разом із вирішенням проблеми максимального використання генетичного потенціалу продуктивності бджолиних родин потребує суттєвого збільшення посівів медодайних рослин, підвищення їхньої якості та вдосконалення структури кормо-виробництва. Для цього необхідно вкладати кошти у реконструкцію і покращення пасовищ, селекцію медодайних кормових культур, адаптованих до умов тієі чи іншої зони, а також таких, що враховують тенденції кліматичних змін. Підсумовуючи викладене, зазначимо, що підтримка розвитку селекційної діяльності в Україні має здійснюватися системно, з урахуванням кращого зарубіжного досвіду.

Висновки i перспективи подальших досліджень. Стратегічним напрямом розвитку селекційної роботи в бджільництві $є$ наявність ефективних програм селекції, що орієнтовані на підвищення продуктивності бджолородин, зростання їхньої стійкості до хвороб і шкідників. Усього цього можна досягти лише об'єднанням зусиль бджолярів і селекціонерів. При цьому, з метою досягнення ефективної результативності бджільництва, вираженої у співвідношенні корисних кінцевих результатів ії функціонування до витрачених ресурсів, постає необхідність у впровадженні методів і прийомів, які грунтуються на науковій організації праці, прогресивному досвіді розвинених країн і досягненнях аграрної та економічної наук у даній сфері.

Основним напрямом збільшення та здешевлення виробництва продукції бджільництва $\epsilon$ послідовна інтенсифікація галузі. Вона передбачає зміцнення кормової бази, поліпшення племінних і продуктивних якостей бджолородин, запровадження нових технологій, індустріалізацію виробництва й удосконалення організаційних форм у галузі.

Отже, бджільництво має розвиватися на промисловій основі та лише об'єднуючи всі фактори які мають дійсний вплив на продуктивність бджолиної родини в збалансованому вигляді, можна досягти зменшення затрат матеріальних та трудових ресурсів.

Розробка та реалізація напрямів і заходів щодо стимулювання розвитку селекційної діяльності в контексті економічної ефективності бджільництва сприятиме підвищенню продуктивності бджолиних родин, зниженню матеріально - грошових затрат з розрахунку на одну бджолину родину.

\section{Джерела та література}

1. Поліщук В. П. Бджільництво. - Львів: Редакція журналу "Український пасічник", 2001.- 296 с.

2. Перспективи розвитку економіки України: теорія, методологія, практика: матер. XXIV Міжнар. наук.практ. конф. (22-23 трав. 2019 р.) / відп. ред. Л. Г. Ліпич. - Луцьк : Вежа-Друк, 2019. - 132 с.

3. Сумарний обсяг імпорту та експорту у розрізі товарних позицій за кодами УКТЗЕД 409 „Мед натуральний” [Електронний ресурс]. - Режим доступу: http://sfs.gov.ua/ms/f11.

4. Товарна структура зовнішньої торгівлі у 2018 році [Електронний ресурс]. - Режим доступу: http://www.ukrstat.gov.ua/operativ/operativ2018/zd/tsztt/tsztt_u/tsztt1218_u.htm. 
5. Молоцький М. Я. Васильківський С. П. Князюк В. І. Селекція і насінництво сільськогосподарських рослин- Київ: Видавництво «Вища освіта» - 2006 - 458c.

6. Beekeeping in the Buckast Abbey Article by Brother Adam, O. S. B., St. Mary's Abbey, Buckfast, Devon, England- First edition - 1975, 150 p.

7. Малков В.В Племенная работа на пасеке - Москва: Россельхозиздат , 1985.

8. Фридрих Руттнер Техника разведения и селекционный отбор пчел: практическое руководство.. - 7 изд. - Москва: АСТ Астрель, 2006.

9. Шубравська О.В Розвиток селекційної діяльності та ринку селекційної продукції в Україні та світі. $2012-13 \mathrm{c}$.

10.Закон України „Про бджільництво" [Електронний доступу: https://zakon.rada.gov.ua/laws/show/1492-14

11. Постанова КМУ від 7 лютого 2018 р. № 106 „Про затвердження Порядку використання коштів, передбачених у державному бюджеті для надання фінансової підтримки розвитку фермерських господарств” [Електронний ресурс]. - Режим доступу: https://zakon.rada.gov.ua/laws/show/106-2018-\%D0\%BF

12. Т. Губиной Пчела и улей (сборник статей). Москва. „Колос” 1960, 503c.

\section{References}

1. Polishhuk V. P. Bdzhil`ny`cztvo. - L`viv: Redakciya zhurnalu "Ukrayins`ky`j pasichny`k", 2001.- 296 s. [in Ukrainian].

2. Perspekty`vy` rozvy`tku ekonomiky` Ukrayiny`: teoriya, metodologiya, prakty`ka: mater. XXIV Mizhnar. nauk.-prakt. konf. (22-23 trav. 2019 r.) / vidp. red. L. G. Lipy`ch. - Lucz`k : Vezha-Druk, 2019. - 132 s. [in Ukrainian].

3. Sumarny`j obsyag importu ta eksportu u rozrizi tovarny`x pozy`cij za kodamy` UKTZED 409 „Med natural 'ny`j” [Elektronny`j resurs]. - Rezhy`m dostupu: http://sfs.gov.ua/ms/f11. [in Ukrainian].

4. Tovarna struktura zovnishn`oyi torgivli u 2018 roci [Elektronny`j resurs]. - Rezhy`m dostupu: http://www.ukrstat.gov.ua/operativ/operativ2018/zd/tsztt/tsztt_u/tsztt1218_u.htm. [in Ukrainian].

5. Molocz`ky`j M. Ya. Vasy`l`kivs`ky`j S. P. Knyazyuk V. I. Selekciya i nasinny`cztvo sil`s`kogospodars`ky`x rosly`n- Ky`yiv: Vy`davny`cztvo «Vy`shha osvita»-2006-458s. [in Ukrainian].

6. Beekeeping in the Buckast Abbey Article by Brother Adam, O. S. B., St. Mary's Abbey, Buckfast, Devon, England- First edition - 1975, 150 r.

7. Malkov V.V Plemennaya rabota na paseke . Moskva: Rossel xozy`zdat, 1985. [in Ukrainian].

8. Fry`dry`x Ruttner Texny`ka razvedeny`ya y` selekcy`onnыj otbor pchel: prakty`cheskoe rukovodstvo.. - 7 y`zd. - Moskva: AST Astrel’, 2006.

9. Rozvy`tok selekcijnoyi diyal’nosti ta ry`nku selekcijnoyi produkciyi v Ukrayini ta sviti UDK 631.52:63. Shubravs`ka O.V., d-r ekon. nauk zaviduvach viddilu Insty`tutu ekonomiky` ta prognozuvannya NAN Ukrayiny`2012 -13 s. [in Ukrainian].

10.Zakon Ukrayiny` „Pro bdzhil`ny`cztvo" [Elektronny’j resurs]. - Rezhy`m dostupu: https://zakon.rada.gov.ua/laws/show/1492-14. [in Ukrainian].

11. Postanova KMU vid 7 lyutogo 2018 r. \# 106 „Pro zatverdzhennya Poryadku vy`kory`stannya koshtiv, peredbacheny`x u derzhavnomu byudzheti dlya nadannya finansovoyi pidtry`mky` rozvy`tku fermers`ky`x gospodarstv" [Elektronny`j resurs]. - Rezhy`m dostupu: https://zakon.rada.gov.ua/laws/show/106-2018-\%D0\%BF. [in Ukrainian].

12. Pchela y` ulej (sborny`k statej). T. Guby`noj. Moskva: „Kolos” 1960, 503s. [in Ukrainian]. 